\title{
SOIL BIOMASS AND MICROBIAL ACTIVITY IN SOYBEAN CROP AREA UNDER DIFFERENT COVER CROPS AND DIFFERENT SOIL CORRECTION SYSTEMS
}

\author{
BIOMASSA E ATIVIDADE MICROBIANA DO SOLO EM ÁREA DE CULTIVO DE \\ SOJA SOB DIFERENTES PLANTAS DE COBERTURA E DIFERENTES SISTEMAS \\ DE CORREÇÃO DE SOLO
}

\author{
Jéssica Ferreira DINIZ ${ }^{1}$; Cassiano Garcia ROQUE ${ }^{1}$; \\ Monica Cristina Rezende Zuffo BORGES ${ }^{2}$; Pedro Paulo Vilela BARROS ${ }^{\mathbf{1}}$; \\ Paulo Henrique Menezes das CHAGAS ${ }^{1}$; Othon Lauar GODINHO ${ }^{1}$; \\ Paulo Eduardo TEODORO ${ }^{1 *}$ \\ 1. Universidade Federal de Mato Grosso do Sul - UFMS, Chapadão do Sul, MS, Brasil; 2. Universidade Federal do Vale do São \\ Francisco - UNIVASF, Petrolina, PE, Brasil. eduteodoro@hotmail.com
}

\begin{abstract}
This study aimed to evaluate soil biomass and microbial activity and soybean yield under different limestone and gypsum doses and different cover crops. The experiment was carried out in the experimental area of the Fundação de Apoio a Pesquisa Agropecuária de Chapadão, on a Dystrophic Red Latosol, using cultivar Desafio. The experiment consisted of a randomized blocks design, in a split-plot factorial scheme $(3 \times 4 \times 3)$, with three replications. Plots consisted of three gypsum doses: control (without gypsum), recommended dose $\left(2.3 \mathrm{Mg} \mathrm{ha}^{-1}\right)$, and double dose $\left(4.6 \mathrm{Mg} \mathrm{ha}^{-1}\right)$. Subplots consisted of four limestone doses $\left(2,4\right.$, and $\left.6 \mathrm{Mg} \mathrm{ha}^{-1}\right)$ and the control (without limestone). Each block had three different cover crops: Brachiaria, Millet, and allow. The values obtained with the test revealed that brachiaria had better basal respiration in the absence of gypsum. Conversely, millet had better basal respiration in with the gypsum dose. Basal respiration, using brachiaria as cover crop, was higher at the dose of $2700 \mathrm{~kg} \mathrm{ha}^{-1}$ of limestone. However, for the fallow and the millet, basal respiration was higher when using the highest limestone dose of $6000 \mathrm{~kg} \mathrm{ha}^{-}$ 1. The variable microbial biomass showed differences between cover crops only in the absence of gypsum. Brachiaria and fallow presented the highest mean for microbial biomass. The use of millet as a cover crop together with gypsum doses increased the microbial biomass. The variables mass of 100 grains and grain yield had higher mean at the limestone dose of $6000 \mathrm{~kg} \mathrm{ha}^{-1}$.
\end{abstract}

KEYWORDS: Microbial biomass. Microbial activity. Limestone. Gypsum. Millet. Brachiaria.

\section{INTRODUCTION}

Nowadays, agriculture has given more attention to practices that aim at lower soil degradation and greater sustainability. The use of cover crops is an ecological and economical alternative to an efficient soil management, allowing the balance of physical, chemical, and biological properties of the soil-plant system (SOUZA et al., 2008).

Cover crops, such as millet (Pennisetum glaucum) and brachiaria (Urochloa riziziensis) in the Cerrado have stood out due to their high organic matter production, continuous and deep root growth, soil preservation ability (such as improving structure, aggregation, permeability, infiltration), nutrients recycling ability (BETTIOL et al., 2015). These facts were reported by Torres et al. (2008), who concluded that millet was one of the cover crops with the highest phytomass production and $\mathrm{N}$ accumulation, and brachiaria had the highest decomposition rate.

According to Duarte et al. (2014), cover crops altered soil microbial biomass, its activity, and its derivatives and indices.

Among the soil biological characteristics, soil microbial biomass is defined as a living microbial component of the soil, composed of bacteria, fungi, protozoa, actinomycetes, and algae, which act in the decomposition process of organic residues by promoting nutrients cycling and the energy flow in the soil (CARDOSO, 2004). The high rate of microbial respiration is indicative of high activity, which reflects in the mineralization rate of the organic matter that will contribute to greater nutrients availability to the crop. Thus, the maximum potential of the soil can be known by the determination of microbial respiration.

Cerrado soils present acidity, aluminum toxicity, and are poor in nutrients. These are limiting 
factors to agricultural production. Liming is the best practice for soil correction since it enables achieving the maximum crop yield, with the benefit of neutralizing soil acidity, providing calcium and magnesium, reducing aluminum toxicity, increasing nutrient availability, and increasing soil bases saturation. However, in the no-tillage system, liming is performed by applying limestone to the soil surface, without incorporation (NETO, 2016).

Surface liming without incorporation does not reach the deeper layers of the soil and consequently does not correct the acidity at greater depths. Therefore, gypsum is used together with liming. Agricultural gypsum acts as a soil conditioner, improving nutrients availability on the subsurface layers. Gypsum has been used in soybean, corn, pasture, and in perennial crops, such as sugarcane, increasing yield due to the more efficient use of water and soil nutrients (DEMATTÊ et al., 2011; RAMPIM et al., 2013).

The application of limestone and gypsum can influence the development of cover crops, causing them to produce a greater amount of dry matter and to develop a better root system, besides providing minerals to the soil. Such results may influence soybean yield, as well as biomass and soil microbial activity.

This study aimed to evaluate the soil biomass and microbial activity and soybean yield under the effect of different limestone and gypsum doses and different cover crops.

\section{MATERIAL AND METHODS}

The experiment was carried out at the Foundation for Agricultural Research Support of Chapadão, in the municipality of Chapadão do Sul, MS (18 41'33"S, 5240'45"W, alt. $810 \mathrm{~m}$ asl). According to Köppen, the climate is classified as tropical humid (Aw). The soil of the experimental area was classified as medium-textured, Dystrophic Red Latosol. The experimental area had been under no-tillage system for six years. Limestone had been applied to increase the base saturation to $50 \%$, and gypsum was used at the implantation of the notillage system. Cover crops were sown in October 2015 , with 5 and $15 \mathrm{~kg} \mathrm{ha}^{-1}$ seeds of $U$. ruziziensis and P. glaucum (cv ADR 300), respectively, using a mismatched disk seeder, with a spacing of $0.17 \mathrm{~m}$ between rows.

The experiment consisted of a randomized blocks design, in a split-plot factorial scheme $(3 \times 4 \times 3)$, with three replications. The plots consisted of three gypsum doses, with the following measures: control (without gypsum), recommended dose (2.3 $\mathrm{Mg} \mathrm{ha}{ }^{-1}$ ), and double dose (4.6 $\left.\mathrm{Mg} \mathrm{ha}^{-1}\right)$. The subplots consisted of four limestone doses $(2,4$, and $6 \mathrm{Mg} \mathrm{ha}^{-1}$ ), and a control (without limestone). Each block had three different cover crops: Braquiaria, Millet, and fallow. Plots had $3.15 \times 22 \mathrm{~m}$, and the subplots had $3.15 \times 5.5 \mathrm{~m}$. With subplots, the three central rows were considered as useful area, excluding $0.5 \mathrm{~m}$ of their extremities.

Soybean (variety Desafio) was cultivated in the experimental area. After harvest, at the end of 2016, the variables of one hundred grain mass (HGM) and grain yield. At the beginning of 2017, the soil was collected at $0-10$ depth for the evaluation of carbon biomass (SMB) and basal respiration (SBR).

The 100-grain mass was determined by the random collection of two samples of 100-grains per plot. Yield was evaluated by counting, harvesting, and mechanical tracing of plants in the useful. Grains were weighed and transformed into $\mathrm{kg} / \mathrm{ha}$ (13\% wet basis).

The SMB was determined using the fumigation-extraction method of Polli \& Guerra (1997), by determining the carbon of the fumigated and non-fumigated samples, by dichromatometry. SBR was determined using the $\mathrm{CO} 2$ value emitted by the non-fumigated samples during the incubation period in the BOD, reflecting the microbial activity.

Results were subject to analysis of variance. The factors cover crops and gypsum doses were subject to means comparison by the Tukey's test. The factor limestone dose was subject to polynomial regression analysis. In all cases, $5 \%$ probability was adopted. All analyses were performed in the Sisvar software.

The analysis of variance for carbon biomass (SMB), basal respiration (SBR), one hundred grain mass (HGM), and yield (Y) is presented in Table 1. The factor cover crops influenced only SBR, which was also influenced by gypsum doses. The isolated limestone effect influenced SBR, HGM, and Y. Results revealed Cover crops $\mathrm{x}$ gypsum doses interaction for SMB and SBR. Cover crops $\mathrm{x}$ limestone doses interactions were significant only for SBR, which was also influenced by the gypsum doses $\mathrm{x}$ limestone doses interaction.

The cover crop and soil management also promote changes in its physical and chemical properties, affecting the microbial activity, and consequently the potential of soil use for cultivation (MOREIRA; SIQUEIRA, 2006). 
Table 1. Summary of the analysis of variance for carbon biomass (SBM), basal respiration (SBR), one hundred grain mass (HGM), and grain yield (Y) of soybean cultivated under different cover crops and limestone and gypsum doses

\begin{tabular}{llllll}
\hline Source of variation & DF & SMB & SBR & HGM & Y \\
\hline Block & 2 & 6.37 & 366.92 & 1.83 & 263973.69 \\
Cover crop (C) & 2 & $38.86^{\mathrm{ns}}$ & $2103.61^{*}$ & $0.10^{\mathrm{ns}}$ & $678185.25^{\mathrm{ns}}$ \\
Gypsum (G) & 2 & $835.69^{\mathrm{ns}}$ & $3602.40^{*}$ & $0.16^{\mathrm{ns}}$ & $176645.02^{\mathrm{ns}}$ \\
Limestone (L) & 3 & $645.09^{\mathrm{ns}}$ & $5362.05^{*}$ & $4.87^{*}$ & $1173481.78^{*}$ \\
C x G & 4 & $4048.83^{*}$ & $7898.21^{*}$ & $0.08^{\mathrm{ns}}$ & $70436.20^{\mathrm{ns}}$ \\
C x L & 6 & $908.56^{\mathrm{ns}}$ & $4599.89^{*}$ & $0.32^{\mathrm{ns}}$ & $186651.10^{\mathrm{ns}}$ \\
G x L & 6 & $2035.52^{\mathrm{ns}}$ & $3185.017^{*}$ & $0.24^{\mathrm{ns}}$ & $159112.98^{\mathrm{ns}}$ \\
\hline Error 1 & 4 & 466.41 & 118.95 & 0.19 & 105726.64 \\
Error 2 & 8 & 11.09 & 204.36 & 0.04 & 31746.07 \\
Error 3 & 70 & 69.05 & 109.76 & 0.26 & 71953.14 \\
\hline
\end{tabular}

ns, *: not significant and significant at $5 \%$ probability by the $\mathrm{F}$ test, respectively.

At lower gypsum doses, millet and fallow obtained the highest mean SBR (Table 2). However, brachiaria and millet presented the highest values for SBR at the highest gypsum dose $\left(4600 \mathrm{~kg} \mathrm{ha}^{-1}\right)$. High respiration rates indicate that soil microorganisms are under stress, whereas low rates imply a balance in the microbial community, under favorable conditions. According to Moreira (2016), gypsum may cause this stress. Bernardes \& Santos (2016) studies the microbial population using the gypsum as one of the management systems and reported that the possible changes in the microbial population may be related to the soil chemical and physical conditions.

Table 2. Unfolding of the cover crops $x$ gypsum doses interaction for basal respiration in soybean cultivation.

\begin{tabular}{llll}
\hline \multirow{2}{*}{ Cover crop } & \multicolumn{3}{l}{ Gypsum doses $\left(\mathrm{kg} \mathrm{ha}^{-1}\right)$} \\
\cline { 2 - 4 } & 0 & 2300 & 4600 \\
\hline Brachiaria & $88.32 \mathrm{bB}$ & $69.96 \mathrm{Bc}$ & $109.08 \mathrm{aA}$ \\
Fallow & $108.05 \mathrm{aA}$ & $98.08 \mathrm{Aa}$ & $55.05 \mathrm{bB}$ \\
Millet & $114.19 \mathrm{aA}$ & $82.50 \mathrm{abB}$ & $115.87 \mathrm{aA}$ \\
\hline
\end{tabular}

Means followed by lower case letters in the same column and upper case on the same row do not differ by the Tukey's test at 5\% probability.

Torres et al. (2008) reported that millet was one of the cover crops with higher phytomass production and $\mathrm{N}$ accumulation. Greater amounts of phytomass enrich the soil with organic matter and nutrients, influencing the microbial biomass that acts in the decomposition process of organic residues and nutrient cycling.

Fallow and millet showed an increasing linear behavior in response to the limestone doses, reaching the highest values at the dose of $6000 \mathrm{~kg}$ $\mathrm{ha}^{-1}$ (Figure 1). Conversely, a quadratic response was detected for brachiaria, whose maximum respiration was obtained with the limestone dose of $2700 \mathrm{~kg} \mathrm{ha}^{-1}$. The coefficients of determination $\left(\mathrm{R}^{2}\right)$ indicated adequate adjustment of the models in response to limestone doses. Similarly, Schneider et al. (2011) concluded that soil liming increased soil microbiota, which influenced the respiration rates.

Brachiaria presents an intermediate degree of adaptation to the conditions of fertility and bases saturation, being a more rustic species, not very demanding in relation to fertility, as shown in recommendation tables elaborated according to the experimentation and consensus between researchers of Embrapa Gado de Corte and Embrapa Cerrados. The recommended base saturation and fertilization are $40 \%$ and a maximum of $5000 \mathrm{~kg} \mathrm{ha}^{-1}$, respectively, as reported by Coan (2008), in an adaptation of Werner et al. (1996).

The increase of limestone dose promoted a linear increase of this variable at the extreme gypsum doses ( 0 and $\left.4600 \mathrm{~kg} \mathrm{ha}^{-1}\right)$, with $\mathrm{R}^{2}$ higher than $80 \%$ (Figure 2). For the intermediate gypsum dose $\left(2300 \mathrm{~kg} \mathrm{ha}^{-1}\right)$, any of the linear models tested could me adjusted. Bettio \& Araújo (2016) concluded that mineral fertilization resulted in microbial changes, and the respiration rate had a higher mean in the treatment with limestone and gypsum. 


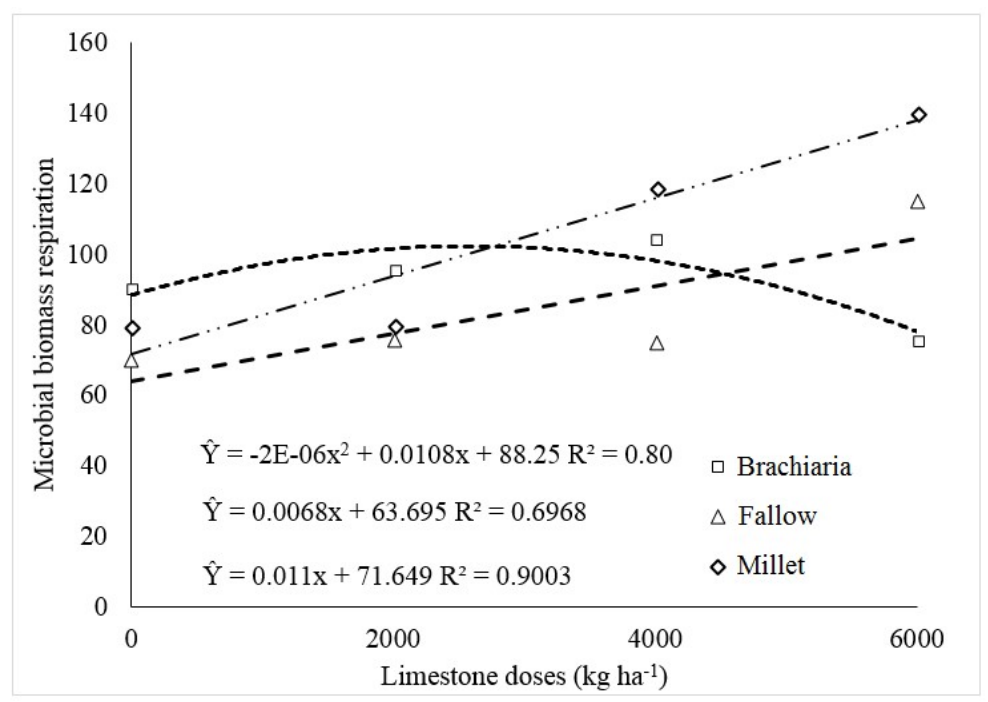

Figure 1. Unfolding of the significant limestone doses $\mathrm{x}$ crop cover interaction for microbial biomass respiration.

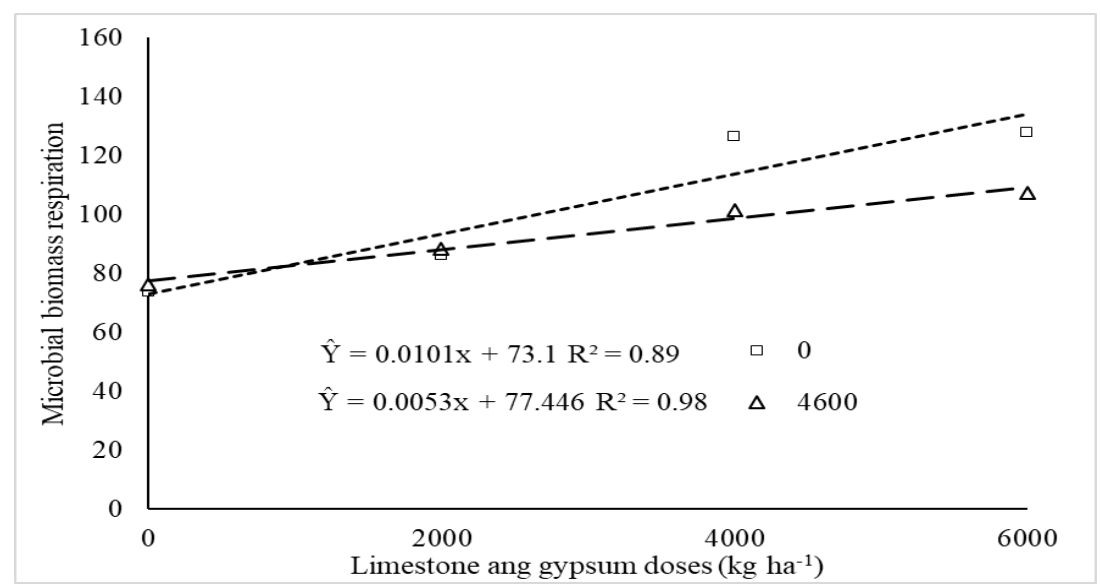

Figure 2. Unfolding of the significant limestone doses $\mathrm{x}$ gypsum doses interactions for microbial biomass respiration.

Table 3 shows that difference between the cover crops for SMB only in the absence of gypsum. Conversely, brachiaria and fallow presented the highest means for this variable. Gypsum application, regardless of the dose (2300 and $\left.4600 \mathrm{~kg} \mathrm{ha}^{-1}\right)$, did not influence the cover crops for SMB. For the brachiaria, the absence of gypsum promoted approximately twice the SMB when compared with the treatment with gypsum application. For the fallow, gypsum application did not increase this variable. However, the use of millet as a cover crop together with gypsum doses increased SMB.

Table 3. Unfolding of the cover crops $\mathrm{x}$ gypsum doses interaction for carbon biomass in soybean cultivation.

\begin{tabular}{llll}
\hline \multirow{2}{*}{ Cover crop } & \multicolumn{2}{l}{ Gypsum doses $\left(\mathrm{kg} \mathrm{ha}^{-1}\right)$} & 4600 \\
\cline { 2 - 4 } & 0 & 2300 & $27.87 \mathrm{aB}$ \\
\hline Brachiaria & $60.88 \mathrm{aA}$ & $36.33 \mathrm{Ab}$ & $29.39 \mathrm{aA}$ \\
Fallow & $51.56 \mathrm{aA}$ & $50.28 \mathrm{Aa}$ & $54.03 \mathrm{aA}$ \\
Millet & $22.10 \mathrm{bB}$ & $51.18 \mathrm{Aa}$ & $\mathrm{ab}$
\end{tabular}

Means followed by lower case letters in the same column and upper case in the same row do not differ by the Tukey's test at $5 \%$ probability.

The microorganisms are responsible for the mineralization of the organic matter, and thus, the more available the cover crop, the greater is the
SMB. The effect of cover crops on the organic matter accumulation in the soil and on the improvement of its biological attributes should be 
quantified regionally and for each production system. This is because this process depends on soil texture and mineralogy, relief, and temperature and humidity conditions (CUNHA et al., 2011).

The ability to better use nutrients results in a vigorous growth, reaching two meters in height. Another advantage of millet is the slow straw decomposition, which gradually releases the nutrients absorbed by the plant, making them available for subsequent crops (CHAGAS, 2004).

In this case, gypsum contributed to the increase in $\mathrm{SMB}$, and it may have caused changes in the dry biomass production of millet, unlike the results obtained by Carvalho \& Nascente (2014), who reported that the gypsum application did not change the dry biomass production of millet. The use of agricultural gypsum has provided large increases in yield. These increases are mainly attributed to the better development of the root system, which improves water and nutrients absorption.

Unlike the results obtained for brachiaria in the work of Guedes et al. (2000), the gypsum application increased the dry matter production of the studied cover crop. However, no significant responses were recorded with fertilizations higher than $0.5 \mathrm{t} / \mathrm{ha}$. This is because brachiaria is more rustic and does not respond so well to heavier fertilization

Limestone was the only treatment that influenced the soybean agronomic components. Figures 3 and 4 show a linear increase of one hundred grain mass and yield in response to limestone doses up to $6000 \mathrm{~kg} \mathrm{ha}^{-1}$.

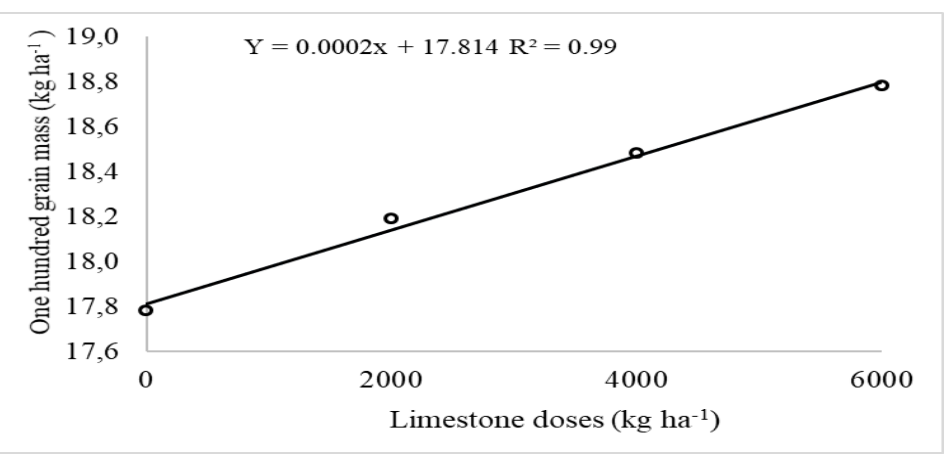

Figure 3. Response of one hundred grain mass of soybean plants to limestone doses.

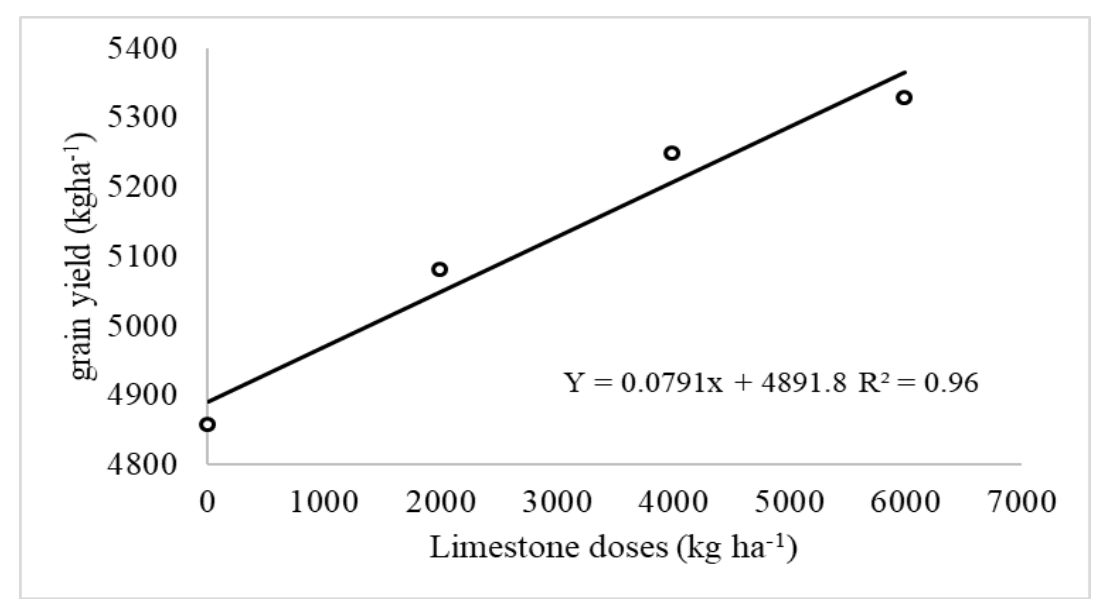

Figure 4. Response of soybean grain yield to limestone doses.

Liming is an essential practice to achieving crop yield ceilings since it neutralizes soil acidity, provides calcium and magnesium, reduces aluminum toxicity, increases nutrient availability, and increases soil base saturation. Correction of soil acidity by liming is the first step to obtain a highly productive crop (SFREDO, 2008). Veronese et al. (2012) reported that the higher the limestone dose, the higher is the soybean yield, which is consistent with the present results.

\section{ACKNOWLEDGMENTS}

This study was partially funded in part by the Brazilian Conselho Nacional de Desenvolvimento Cienfico e Tecnológico (CNPq), Coordination of Improvement of Higher Education Personnel - Brazil (CAPES) - Finance Code 001, Fundação de Apoio ao Desenvolvimento do Ensino, Ciência e Tecnologia do Estado de Mato Grosso do 
Sul. and Federal University of Mato Grosso do Sul (UFMS).

RESUMO: O objetivo do trabalho foi avaliar a biomassa e atividade microbiana do solo, e produtividade da soja sob efeito das diferentes doses de calcário e gesso e diferentes coberturas de solo. O experimento foi conduzido na área experimental da Fundação de Apoio a Pesquisa Agropecuária de Chapadão, sob Latossolo Vermelho Distrófico, com a cultivar Desafio. O delineamento experimental utilizado foi em blocos casualizados, em esquema fatorial $(3 \times 4 \times 3)$ de parcelas subdividas, com 3 repetições. As parcelas foram constituídas por 3 quantidades de gesso agrícola, sendo: controle (sem gesso), recomendado $\left(2,3 \mathrm{Mg} \mathrm{ha}^{-1}\right)$ e o dobro (4,6 $\left.\mathrm{Mg} \mathrm{ha}^{-1}\right)$, as subparcelas por 4 doses de calcário $\left(2,4 \mathrm{e} 6 \mathrm{Mg} \mathrm{ha}^{-1}\right)$, além do controle (sem calcário), onde cada bloco apresentou 3 coberturas diferentes: Braquiaria, Milheto e Pousio. Os resultados foram submetidos ao teste de Tukey 5\%. Com os valores obtidos pudemos observar que a respiração basal foi melhor para braquiária na ausência de gesso, e na presença o milheto se saiu melhor. A respiração basal, utilizando a braquiária como cobertura, foi maior na dose de $2700 \mathrm{~kg} \mathrm{ha}^{-1}$ de calcário. Já utilizando o pousio e o milheto foi na maior dose $6000 \mathrm{~kg} \mathrm{ha}^{-1}$. A variável biomassa microbiana apresentou diferença entre as coberturas apenas na ausência de gesso, onde a braquiária e o pousio apresentaram as maiores médias para esta variável. A utilização do milheto como cobertura em conjunto com as doses de gesso acarretou aumento da biomassa microbiana. A massa de 100 grãos e a produtividade de grãos apresentaram maior média na dose de $6000 \mathrm{~kg} \mathrm{ha}^{-1}$ de calcário.

PALAVRAS-CHAVE: Biomassa microbiana. Atividade microbiana. Calcário. Gesso. Milheto. Braquiária.

\section{REFERENCES}

BERNARDES, C. M.; SANTOS, M. A. População microbiana como indicadora de interferência de diferentes manejos de solos de cerrado com cultivo de soja. Bioscience Journal, Uberlândia, v. 22, n. 2, p. 7-16, 2006.

BETTIO, D. P; ARAÚJO, F. F. Alterações microbiológicas do solo após três anos de sistema integração lavoura - pecuária sob diferentes adubações e escarificação do solo. Colloquium Agrariae, Presidente Prudente, SP, v. 12, n. Especial, p. 01-07, 2016. https://doi.org/10.5747/ca.2016.v12.nesp.000163

BETTIOL, J. V. T.; PEDRINHO, A.; MERLOTI, L. F.; BOSSOLANI, J. W.; SÁ, M.E. de. Plantas de Cobertura, Utilizando Urochloa ruziziensis solteira e em Consórcio com Leguminosas e seus Efeitos Sobre a Produtividade de Sementes do Feijoeiro. Uniciências, Londrina, PR, v. 19, n. 1, p. 3-10, 2015.

CARDOSO, M. O. Método para quantificação da biomassa microbiana do solo. Agropecuária Técnica, v. 25, p. 1-12, 2004.CLAESSEN, M. E. C. (Org.). Manual de métodos de análise de solo. 2. ed. rev. atual. Rio de Janeiro: Embrapa Solos, 1997. 212 p. (Embrapa-CNPS. Documentos, 1).

CARVALHO, M. da C. S; NASCENTE, A. S. Calcário, gesso e efeito residual de fertilizantes na produção de biomassa e ciclagem de nutrientes de milheto. Pesquisa Agropecuária Tropical, Goiânia, v. 44, n. 4, p. 370 380, 2014. https://doi.org/10.1590/S1983-40632014000400008

CHAGAS, R. C. S. Avaliação de fontes de silício para as culturas do arroz e milheto. Tese (doutorado)Centro de Energia Nuclear na Agricultura, Universidade de São Paulo, Piracicaba,SP, p.80 2004.

COAN, R. M. Calagem em pastagens tropicais. Artigos Técnicos, Jaboticabal, SP,2008.

CUNHA, E. Q.; STONE, L. F.; FERREIRA, E. P. B.; DIDONET, A.D.; MOREIRA, J. A. A.; LEANDRO, W. M. Sistemas de preparo do solo e culturas de cobertura na produção orgânica de feijão e milho. II - atributos biológicos do solo. Revista Brasileira de Ciência do Solo, Viçosa, v. 35, n. 2, p.603-611, 2011. https://doi.org/10.1590/S0100-06832011000200029 
DEMATTÊ, J. L. I.; PAGGIARO, C. M.; BELTRAME, J. A.; RIBEIRO, S. S. Uso de silicatos em cana-deaçúcar. Informações Agronômicas, Piracicaba, SP, n.133, p. 7-12, 2011.

DUARTE, I. B.; GALLO, A. S.; GOMES, M. S; GUIMARÃES, N. F; ROCHA, D. P.; SILVA, R. F. Plantas de cobertura e seus efeitos na biomassa microbiana do solo. Acta Iguazu, Cascavel, PR, v. 3, n. 2, p. 150-165, 2014.

GUEDES, L. M.; GRAÇA, D. S.; MORAIS, M. G.; ANTUNES, R. C.; GONÇALVES, L. C. Influência da aplicação de gesso na produção de matéria seca, na relação nitrogênio: enxofre e concentrações de enxofre, cobre, nitrogênio e nitrato em pastagens de Brachiaria decumbens Stapf. Arquivo Brasileiro de Medicina Veterinária e Zootecnia, Belo Horizonte, MG, v. 52, 2000. https://doi.org/10.1590/S010209352000000500019

MOREIRA, F. M. S.; SIQUEIRA, J. O. Microbiologia e bioquímica do solo. Lavras: UFLA, 2006.

MOREIRA, M. C. D. L. Indicadores de qualidade biológica de um latossolo argiloso sob diferentes sistemas de manejo. Dissertação (mestrado)- Universidade Estatual do Oeste do Paraná, Cascavel, 2016.

NETO, J. F. Qualidade física e química do solo em função do sistema de produção e da aplicação superficial de silicato e calcário em experimento de longa duração. (Tese de Doutorado- Universidade Estadual Paulista, Botucatu. 184p., 2016.

RAMPIM, L.; LANA, M. C.; FRANDOLOSO, J. F. Fósforo e enxofre disponível, alumínio trocável e fósforo remanescente em Latossolo Vermelho submetido ao gesso cultivado com trigo e soja. Semina: Ciências Agrárias, Londrina, PR, v. 34, n. 4, p. 1623-1638, 2013. https://doi.org/10.5433/1679-0359.2013v34n4p1623

SCHNEIDER, J.; KLAUBERG FILHO, O.; FONTOURA, S. M.; ALVES, M. V. Infuência de diferentes sistemas de manejo e calagem em experimento de longa duração sobre fungos micorrízicos arbusculares. Ciência e Agrotecnologia, Lavras, MG, v. 35, n. 4, p. 701-709, 2011. https://doi.org/10.1590/S141370542011000400008

SFREDO, G. J. Soja no Brasil: calagem, adubação e nutrição mineral. Londrina, PR: Embrapa Soja, 2008. 145 p. (Documentos, $\left.\mathrm{n}^{\mathrm{0}} 305\right)$.

SOUZA, K. B.; PEDROTTI, A.; RESENDE, S. C.; SANTOS, H. M. T.; MENEZES, M. M. G.; SANTOS, L. A. M. Importância de Novas Espécies de Plantas de Cobertura de Solo para os Tabuleiros Costeiros. Revista da Fapese, Aracaju, SE, v. 4, p. 131-140, 2008.

TORRES, J. L. R.; PEREIRA, M. G.; FABIAN, A. J. Produção de fitomassa por plantas de cobertura e mineralização de seus resíduos em plantio direto. Pesquisa Agropecuária Brasileira, Brasília, DF, v. 43, n. 3, p. 421-428, 2008. https://doi.org/10.1590/S0100-204X2008000300018

VERONESE, M.; FRANCISCO, E. A. B.; ZANCANARO, L.; ROSOLEM, C. A. Plantas de cobertura e calagem na implantação do sistema plantio direto. Pesquisa Agropecuária Brasileira, Brasília, DF, v. 47, p. 1158-1165, 2012. https://doi.org/10.1590/S0100-204X2012000800017 